\title{
Kestävyyden käsitteen mielekkyys tutkimuksessa
}

\author{
Teppo Eskelinen \& Ville-Pekka Sorsa
}

\begin{abstract}
Abstrakti
Tutkimme tässä artikkelissa kestävyyden (englanniksi sustainability) käsitteen merkitystä, käyttöä ja käyttökelpoisuutta tieteellisessä tutkimuksessa. Pyrimme huomioimaan myös yhteiskunta- ja ihmistieteiden erityisluonteen käsitteen paikkaa ja mahdollisuuksia analysoitaessa. Lähtökohtanamme on, että "kestävyydestä" on tullut liian yleinen, lavea ja jäsentymätön käsite tieteellisessä tutkimuksessa. Käsitettä on vaikeaa käyttää mielekkäästi ja täsmällisesti sen käyttötapojen kirjavuuden vuoksi. Asiaa vaikeuttavat erityisesti epäselvä suhde rinnakkaiskäsitteisiin sekä itse termiin liitetyt normatiiviset lataukset. Pääasiallinen väitteemme on, että kestävyyden käsitettä voidaan käyttää mielekkäästi niin tutkimuskohteen määrittelyssä kuin normatiivisen tutkimusotteen perustana, mutta varsin rajallisesti. Pyrimme täten "pelastamaan" kestävyyden käsitteen määrittelemällä sitä tiukemmin. Samalla myös osoitamme, missä mielessä käsite on ja ei ole normatiivinen.
\end{abstract}

\section{Johdanto}

Kestävyydestä (englanniksi sustainability) on tullut yksi poliittisen kielenkäytön vahvimpia termejä ja houkuttelevimpia ideoita (Cox ja Béland 2013). Termi esiintyy yhtäältä keskusteluissa talouden ja ekologian suhteista (esim. Ekins 1999, Hussen 2012), toisaalta keskusteluissa talousjärjestelmän sisäisestä hallittavuudesta. Talouden ja ekologian suhteisiin se vakiintui YK:n kestävän kehityksen komission työn myötä 1980-luvulla (WCED 1987). "Kestävä talous” oli oman aikansa käsitteellinen lanseeraus, jonka avulla pyrittiin ilmaisemaan ihanne talouskasvusta ilman ekologisten tekijöiden (resurssi-, energia- ja saastenielu jne.) määrittämiä rajoja (Eskelinen 
2006, 73-74). Talousjärjestelmän sisäisistä prosesseista puhuttaessa kestävyydellä taas viitataan tyypillisesti muun muassa epävakaan rahoitusjärjestelmän stabilisoimiseen (Cox ja Béland 2013) tai julkistalouden kurinalaistamiseen (Sorsa 2014).

Tässä artikkelissa pohdimme "kestävyyden" mielekkyyttä tutkimuksellisena käsitteenä. Tämä pohdinta edellyttää, että käsitteen merkityksiä analysoidaan ilman apriorisia normatiivisia latauksia, sivumerkityksiä ja spesifeistä käyttöyhteyksistä nousevia mielleyhtymiä (esim. YK:n kestävän kehityksen periaatteet), joita termin "kestävä" poliittiseen käyttöön ja arkikäyttöön yleisemmin liittyy. Tarkastelemme artikkelissa tieteenfilosofisesti kysymystä kestävyyden käsitteen rajoista, mahdollisuuksista ja mielekkäistä käyttötavoista tieteellisessä tutkimuksessa. Artikkelissa on kyse tutkimuksen metatason käsitteenmäärittelystä ja tutkimuskohteen määrittelystä, minkä vuoksi emme tee laajempaa katsausta kestävyyden käsitettä käyttävään kirjallisuuteen. Tieteenfilosofisessa analyysissa voidaan erottaa lähestymistapoina "puhtaan" käsiteanalyyttinen lähestymistapa ja aineistolähtöisempi tai "naturalistinen" lähestymistapa, joista jälkimmäisessä käsitettä ja tutkimuskohdetta lähestytään olemassa olevan tutkimuksen kautta ja siihen peilaten. Artikkelimme edustaa näistä ensin mainittua suuntausta.

Analysoimme kestävyyttä filosofisena ja teoreettisena käsitteenä sekä empiirisenä tutkimuskohteena. Huomiomme artikkelissa myös kestävyyden tutkimuksen erityisluonteen yhteiskunta- ja ihmistieteissä. Pyrkimyksemme ei ole esittää empiiristä analyysia siitä, millaiset ilmiöt, päätökset ja prosessit ovat tai voivat olla kestäviä, tai minkä pitäisi olla kestävää ja millä lailla kestävää. Emme myöskään tutki "kestävyyttä" yhtenäisenä ilmiönä tai YK:n kestävän kehityksen periaatteiden tavoin erilaisia logiikoita yhteen keräävänä teoreettisena viitekehyksenä, vaan moniin ilmiöihin liittyvänä ominaisuutena. Tavoitteenamme on näin tuottaa kokonaiskuva siitä, mitä tutkimuksessa tehdään, kun siinä tarkastellaan jonkin asian kestävyyttä. Tähän kuvaan sisältyy myös kysymys siitä, missä määrin kestävyyden käsitteen käyttöön liittyy erilaisia oletuksia ja normatiivisia sitoumuksia.

Artikkeli koostuu kahdesta osasta. Ensin keskitymme määrittelemään kestävyyden käsitettä. Tähän kuuluvat termin "kestävä" sanakirjamerkitys ja sivumerkitykset, etymologia ja normatiiviset lataukset sekä kestävyyden tutkimuksellisen käsitteen suhde rinnakkaiskäsitteisiin. Artikkelin toisessa osassa käsittelemme kestävyyttä tutkimuskohteena: mitä itse asiassa 
tutkimme, kun tutkimme sitä, onko tai voiko jokin toimintatapa, järjestelmä tai ilmiö olla kestävä. Lopuksi vedämme yhteen analyysimme tuloksia.

\section{Kestävyyden lyhyt määritelmä}

Englannin kielen keskeiset sanakirjat määrittelevät "kestävyyden" englanninkielisen vastineen "sustainability" yhtäältä jonkin asian käyttämiseksi tuhoamatta sitä täysin, toisaalta jatkuvuuden kautta. "Kestävä" on jotain, mitä voidaan jatkaa kauan (Merriam-Webster) tai ylläpitää tietyllä tasolla (Oxford). Etymologisesti tarkasteltuna adjektiivi sustainable viittaa niin kantokykyyn (bearable), puolustettavuuteen (defensible) kuin kykyyn jatkaa toimintaa.

Kantokyvyn mielessä kestävyyden käsitteen avulla voidaan etsiä ulkoisia rajoja, joiden puitteissa toiminta voi jatkua. Voidaan esimerkiksi sanoa, että turpeen vuotuinen kulutus energiantuotannossa ylittää jatkuvasti sen määrän, mitä uutta turvetta vuodessa muodostuu. Energiantuotannon järjestäminen turvevoiman varaan uuden turpeen volyymin ylittävältä osalta olisi kantokyvyn mielessä kestämätöntä. Puolustettavuus taas viittaa siihen, että jostain asiasta voidaan pitää kiinni olosuhteiden muuttuessa. Tämä konnotaatio on lähtöisin oikeuskäytännöistä. Puolustettavuudessa on kyse tyypillisesti siitä, voidaanko aiemmasta väitteestä tai tulkinnasta pitää kiinni uuden informaation tullessa esiin. Jos esimerkiksi saadaan selville, että turvetta muodostuu vähemmän kuin sitä kyseisellä ajanhetkellä poltetaan, osoittautuu polttamisen volyymi kestämättömäksi - sitä ei voida pitää yllä loputtomiin. Toimintakyvyn jatkuvuuden idea yhdistää nämä molemmat konnotaatiot. Idea viittaa siihen, että toimintaa voidaan jatkaa tiettyjen rajojen sisäpuolella, kun olosuhteiden muutoksiin reagoidaan - ellei muuten, niin rajoja muuttamalla, mikäli se vaan on mahdollista. Turpeen uusiutumista ei pystytä merkittävästi nopeuttamaan, mutta turpeenpolton määrää ja energiankulutusta voidaan päättää vähentää.

Suomen kielessä termi "kestävä" viittaa paitsi ajalliseen jatkuvuuteen ja pitkäkestoisuuteen, myös vahvuuteen tai lujuuteen. Siinä missä Oxfordin sanakirjan käsitteen "sustainability" yksi merkitys on "puolustettavissa oleva”, suomeksi "kestävä” tuntuisi viittaavan pikemmin siihen, että asia tehdään alun perin niin lujaksi, että se puolustaa itseään. Englanninkielisen 
käsitteen konnotaatiot ovat näistä lähempänä sanan käyttöä tutkimuksessa ja yhteiskunnallisessa keskustelussa. Käsite "kestävä” viittaa tyypillisimmissä käyttötarkoituksissaan nimenomaan kykyyn puolustaa tai toimia muuttuvissa olosuhteissa, ei niinkään staattiseen ominaisuuteen tai puolustamisen tapaan. Kestävyyden käsite viittaa väistämättä jonkinlaiseen pysyvyyden ja joustavuuden tasapainoon: sen kautta tunnistetaan jokin merkityksellinen pysyvä ydin, jonka puolustamisen ohella sallitaan joustavuutta ja muutosta. Suomen termi "kestävä" sisältää tässä mielessä liian vahvan pysyvyyden konnotaation.

Yhteistä kaikille kestävyyden sanakirjamääritelmille on siis viittaus pitkäkestoisuuteen, joka syntyy toiminnan aktiivisen ylläpitämisen kautta. Tyypillisesti pitkäkestoisuuden idea esitetään ilman kummempia lisämääreitä (esim. onko kyseessä tarkka aikamääre vai suhteellinen arvio). Tämä johtuu yhtäältä siitä, ettei mitään järjestelmää tosiasiassa oleteta ikuiseksi, ja toisaalta siitä, että kysymys on ennemmin periaatteellinen kuin empiirinen. Kestävyys on jonkinlainen todennettavissa oleva toimintalogiikka: kestävyyden havaitsemiseksi tai arvioimiseksi ei tarvitse jäädä odottamaan jälkikäteistä havaintoa pitkäkestoisuudesta.

"Kestävä" on myös selvästi positiivinen määre. Kyse on aina jatkuvuudesta jonkun hyvän syyn takia: jatkuvuus ei ole itsetarkoituksellista. Termi on retorisesti vahva ja sen moraalinen painoarvo on usein suurempi kuin sen viittauskohteella. Kestävyyteen vetoamalla on hyvin vaivatonta oikeuttaa ja legitimoida käytäntöjä, vaikka käsitteen viittauskohde ei aina olisi kovin selvä. Samalla kestämättömyys on vahva retorinen argumentti jotain toista käytäntöä vastaan. Usein kestävyyteen liitetään niin voimakkaita normatiivisia latauksia, että koko termin merkitys tuntuu tyhjenevän näihin latauksiin. Tällöin ollaan lähellä puhtaan normatiivista määritelmää "kestävä = hyvä". Tämä johtuu termin "kestävä" normatiivisista sivumerkityksistä, joiden tunnistaminen on relevanttia myös tutkimuksen kannalta.

Termi "kestävä" voi saada ainakin kolmenlaisia normatiivisia sivumerkityksiä. Ensinnäkin määre voi viitata universalisoitavuuteen. Suomen kaltaisen maan kulutustasoa voidaan pitää kestämättömänä sillä perusteella, ettei siitä voi tulla koko ihmiskunnan kattavaa normia: tarvitsisimme ainakin neljän maapallon luonnonvarat, jos kaikkien ihmisten päästöt henkeä kohti olisivat samalla tasolla (Hoffrén 2006). Kokonaistilanne voi siis olla kestävä, mutta yksittäistapaus ei läpäise reilun yleistettävyyden 
testiä. (Toki tällä hetkellä koko ihmiskunta syyllistyy ekologiseen ylikulutukseen, joten huomio on vain periaatteellinen). Toiseksi kestävä voi viitata pelkästään moraaliseen toimintaan tai arvioon. Esimerkiksi suuryrityksen työvoimaa riistävät käytännöt ovat "sosiaalisesti kestämättömiä" tai "kestävän kehityksen vastaisia”. Tässä mielessä kestävyys samastuu terminä legitimiteettiin. Termin käyttö tähän tapaan on kaukana sanakirjamääritelmästä, mutta kuitenkin yleistä paitsi arkipuheessa myös liiketoiminnan etiikan tutkimuksen yhteydessä (esim. Ehrgott ym. 2010, Hutchins ja Sutherland 2008).

Kolmanneksi määreellä "kestävä" on vahva kontrolloitavuuden konnotaatio. Ilmastonmuutos edustaa kestävyyden vastavoimaa paitsi tuhoisien seuraustensa vuoksi myös siksi, että sen irtipäästämää prosessia ei voida enää peruuttaa poliittis-institutionaalisilla välineillä. Tässä mielessä kestämätön on kontrollin ulkopuolella ja siten myös ei-toivottavaa. Tätä kontrolloitavuutta voi pitää termin normatiivisena konnotaationa riippumatta siitä, mihin substantiaalisiin prosesseihin kulloinkin viitataan. Esimerkiksi valtiontalouden kehysbudjetointimenettelyä ajavat virkamiehet puhuvat usein julkistalouden kestävyydestä tarkoittaen ennakoidun rahoitusaseman lisäksi myös omaa kykyään hallita tähän liittyviä prosesseja (Eskelinen ja Sorsa 2011).

\section{Kestävyyden ja rinnakkaiskäsitteiden erot}

Kestävyys voidaan edellä kuvatun perusteella hahmottaa lähtökohtaisesti jonkinlaiseksi samana pysymisen ja muuntautumisen dialektiikkaa kuvaavaksi termiksi, johon sisältyy helposti normatiivisia latauksia. Seuraavaksi siirrymme tarkastelemaan tarkemmin kestävyyden käsitettä tutkimuksen kontekstissa. Kuten edellä totesimme, kestävyyden käsitteeseen liittyy aina jonkinlainen kyky toiminnan aktiiviseen ylläpitoon. Kestävyyden käsitteen erityisyyttä voidaan tutkia erottamalla siitä rinnakkaiskäsitteitä ja analysoimalla niiden eroja kestävyyteen. Keskeisiä tällaisia rinnakkaiskäsitteitä ovat jatkuvuus ja resilienssi. Molemmat voidaan nähdä viittaavan samanlaiseen ilmiöön: systeemien pysymiseen jokseenkin vakaina.

Jatkuvuuden ero kestävyyteen on selkeä, koska jatkuvuus on selvästi konservatiivisempi käsite. Se viittaa siihen, että jokin asia pysyy samanlaisena 
yli ajan. Jatkuvuuden tarkasteluun toisin sanoen riittää, että määritellään jonkin asian identiteetti ja tarkastellaan, onko tämän identiteetin mukaista asiaa olemassa myöhemmällä ajanhetkellä. Myös kestävyyden käsite vaatii jonkin jatkumista - muutenhan kyse olisi muutoksesta. Kestävyyden käsite ei kuitenkaan vaadi samanlaista täydellistä pysyvyyttä. Kestävässä järjestelmässä voi olla jokin muuttumaton ja aikaa kestävä ydin (idea, periaate, ilmiö, käytäntö yms.) ja sen ohella vaihtelevia piirteitä ja ominaisuuksia. Kestävyys viittaa ennemmin pysyvyyttä tuottaviin järjestelmän ominaisuuksiin kuin pysyvyyteen itseensä. Kestävyys kuvaa siten myös järjestelmien latentteja piirteitä ja emergenttejä ominaisuuksia.

Kestävyys on siis syvällisempää tulkintaa vaativa käsite kuin jatkuvuus: kestävyys on selkeämmin analyyttinen ja jatkuvuus kuvaileva käsite. Jatkuvuuden tarkastelu ei vaadi sen tutkimista, mikä tuottaa jatkuvuuden. Ulkoisilla olosuhteilla ja kontekstilla on ylipäätään väliä vain sikäli kun niillä on merkitystä tarkasteltavan asian identiteetin määrittelyn kannalta. Kestävyyden tarkastelu taas vaatii aina sen ymmärtämistä, miksi jokin on kestänyt eli miten jatkuvuutta tuottava tekijä on toiminut erilaisissa olosuhteissa. Kestävyys ei voi olla pelkkä ulkoinen huomio, vaan vaatii aina analyysia kestämisen taustatekijöistä.

Resilienssi on käsitteenä lähempänä kestävyyttä. Kyse on varsinkin yhteiskuntateoriassa yleistyneestä, jopa muodikkaasta käsitteestä, joka viittaa yhteisöjen kykyyn sopeutua ulkoapäin tuleviin muutoksiin ja muutospaineisiin eli järjestelmän kykyyn puolustautua ja palautua vanhaan tilaansa uusissa olosuhteissa. Toisin kuin jatkuvuus, resilienssi korostaa asioiden (lineaarisen) jatkumisen sijaan asioiden katkoksia, muutoksia ja uusintamista epävarmuuden olosuhteissa (Folke 2006). Resilienssiin kuuluu ajatus siitä, että järjestelmän identiteetti ei koskaan pysy täysin samana ulkoisten olosuhteiden muuttuessa. Resilienssin käsite nostaa esiin järjestelmästä jonkinlaisen toiminnallisen ytimen, jonka myötä järjestelmällä on valmius ja kyky pitää valikoituja asioita samana myös uudenlaisissa olosuhteissa (Adger 2000). Käsitteenä se muistuttaa tässä emergenttien ominaisuuksien huomioimisen mielessä hyvin paljon kestävyyttä. Kestävyys on kuitenkin resilienssiä laajempi ja "vaativampi” käsite. Kestävyys vaatii nimittäin sitoutumista resilienssiin.

Otetaan esimerkiksi maanjäristyksen tuhoama kaupunki-infrastruktuuri. Kaupungin kutsuminen resilientiksi ei vaadi, että infrastruktuuri 
rakennetaan millimetrilleen samanlaiseksi - kyse ei ole infrastruktuurin jatkuvuudesta. Pääasia, että kaupungilla on suunnitelma, jonka toteuttamalla asukkaat saavat katon päänsä päälle ja mahdollisuuden liikkua suunnilleen entiseen malliin. Järjestelmä on siis resilientti, jos kaupungilla on todennettu kyky rakentaa jonkinlainen riittävän tasoinen asumis- ja liikenneinfrastruktuuri aina maanjäristyksen sattuessa: kyky rakentaa identtinen infrastruktuuri ei taas ole resilienssin ehto. Kestävä infrastruktuuri puolestaan olisi sellainen, joka joko kestää maanjäristykset ja muut vastaavat olosuhteiden muutokset tai sisältää jo itsessään infrastruktuurin jälleenrakentamisen ominaisuuden. Edellisessä mielessä kestävä infrastruktuuri olisi sellainen, joka ei koskaan edes tarvitse resilienssiä. Mikään ihmisen rakennelma ei ole osoittautunut ikuiseksi, minkä vuoksi kestävyyden käsitteen käyttö vaikuttaisi mielekkäältä lähinnä jälkimmäisessä mielessä. Jälkimmäisessä mielessä kestävä infrastruktuuri olisi sellainen, joka rakentaa itsensä uudelleen. Koska kyse on mitä suurimmalla todennäköisyydellä ihmisten toimintaa ja tietoista päätöstä vaativasta toiminnasta, on kestävyydessä kyse lähtökohtaisesta sitoutumisesta näiden päätösten tekemiseen.

Rinnakkaiskäsitteiden analyysin perusteella kestävyys viittaa aina järjestelmän jonkinlaiseen tahtotilaan. Kestävä järjestelmä on sellainen, joka on sitoutunut tuottamaan järjestelmän joidenkin piirteiden jatkuvuutta, jotka saavat itse järjestelmän toimimaan myös uusissa olosuhteissa. Resilienssi on siis kestävyyden välttämätön, muttei riittävä ehto. Jotta järjestelmä voisi olla pitkäkestoinen, on sen sitouduttava resilienssiin: sen on pyrittävä muuttuvissa olosuhteissa uusiutumaan tai muuttamaan olosuhteita voidakseen pitää kiinni halutuista piirteistä. Kun asiaa väitetään kestäväksi, ei tällöin voida pohtia vain sitä, voiko asia jatkua, vaan on aina pohdittava yhtä lailla sitä, onko asian ylläpitoon todella sitouduttu. Kestävyydessä on kyse ennemmin tietoisesta ja ennalta määriteltyjen kanavien kautta tapahtuvasta kuin satunnaisesta uusintamisesta ja jatkuvuudesta. Tässä mielessä kestävyyden idea poikkeaa merkittävästi epävarmuutta korostavan resilienssin ideasta: kestävyyden idea poistaa tulevaisuuden epävarmuudet kuvasta sitoutumalla kehityskulkujen hallintaan joillakin ennalta määritellyillä tavoilla. 


\section{Kestävyys tutkimuskohteena}

Siirrymme nyt käsittelemään kestävyyttä tutkimuskohteena. Milloin ja millaisilla kriteereillä voidaan sanoa, että jokin järjestelmä on kestävä? Edellä totesimme, että kestävyyden analysoiminen edellyttää aina paitsi pintatason jatkuvuuksien ja emergenttien piirteiden myös niihin sitoutumisen tutkimista: minkälaiset moraaliset, kulttuuriset, juridiset, teknologiset ynnä muut järjestelmät tuottavat ja vahvistavat näitä jatkuvuuksia muuttuvissa asiantiloissa ja olosuhteissa. On muistettava, että tällöin on määriteltävä tarkasti, minkä jatkuvuutta ja uusintamista tarkastellaan. Jotta asian kestävyydestä voisi ylipäätään puhua, ei sen identiteetti voi muuttua kokonaan tunnistamattomaksi - silloin kyse olisi kestävyyden sijaan muutoksesta.

Empiirisesti asian kestävyys voidaan todentaa vain a posteriori. Kestävyyden todentaminen on karkeasti muotoa "asia z on osoittautunut kestäväksi, koska sitä uusintavia mekanismeja n on käytetty tavoilla Mc”. Tässä muotoilussa $\mathrm{z}$ viittaa tutkittavan asian identiteettiin $\mathrm{ja}$ sen rajoihin, $\mathrm{n}$ asian jatkuvuutta tuottaviin mekanismeihin ja M näiden mekanismien käyttöön eri olosuhteissa (c1, c2, jne.). Kestävyyden käsitettä käytetään vain harvoin tällaisessa formaalissa "jälkikäteisessä” mielessä. Kun jotain asiaa kutsutaan tutkimuksessa kestäväksi tai kestämättömäksi, on kyse yleensä kestävyyden "etukäteisestä" arviosta, ei siis varsinaisesta kestävyyden tutkimuksesta. Tämä ei ole yllättävää, sillä kestävyyden käsitteen käyttö vaikuttaa hyödylliseltä lähinnä silloin, kun arvioidaan, vaikuttaako jokin asia kestävältä odotettujen kehityskulkujen puitteissa. Arvio on aina luonteeltaan teoreettinen. Arvion perustana oleva teoria voi toki perustua jonkinlaiseen historialliseen analyysin kaikkien kolmen elementin suhteen.

Kestävyyteen tutkimuskohteena sisältyy kolme merkittävää haastetta, jotka tekevät tutkimuksesta hyvin epävarmaa. Ensimmäinen haaste on se, että kestävyyden varsinainen eli jälkikäteinen tutkimus vaatii aina tutkittavan asian identiteetin määrittelemistä ja "vakiointia" tutkimuksessa. Mikään ei kuitenkaan takaa, että juuri vakioitu asia olisi tutkimuskohteena mielekäs (kiinnostuksen kohteen kannalta validi) tai relevantti. Jos tutkija alkaa tarkastella asian z kestävyyttä, voi tutkimuksessa paljastua, että kestävyyden tuottava mekanismi $\mathrm{n}$ on aluksi esiintynyt asiassa $\mathrm{x}$, joka on muuttunut ensin asiaksi y ja vasta myöhemmin asiaksi z (jota ei vielä välttämättä edes tunnettu x:n aikana). Asia z näyttää kestävyyden tutkimisen 
näkökulmasta lähinnä mielivaltaiselta tutkimuskohteelta. Tätä ei kuitenkaan voida välttää, sillä kestävyyttä tuottavia mekanismeja ei voida irrottaa itse tutkittavasta asiasta: emergentit ominaisuudet ovat aina jonkin asian ominaisuuksia, eikä niihin päästä käsiksi kuin asian esiintymisen ja sen olosuhteiden muutoksien jälkeen.

Näiden epävarmuuksien tuottama haaste on se, että itse asia, jonka kestävyyttä tarkastellaan, "karkaa" aina tutkijalta täsmällisenä tutkimuskohteena. Otetaan esimerkiksi teräksen tuotanto. Voidaan väittää, että materiaalin jatkuva vahvistaminen, hinnan lasku ja materiaalien kierrätys ovat olleet terästeollisuudessa kestävyyttä tuottavia tekijöitä. Nämä ovat näkyneet aiemmin jo valuraudan tuotannossa, joka on muuttunut myöhemmin terästeollisuudeksi. Terästeollisuuden kestävyyden logiikka on siis peräisin jostain muualta kuin juuri teräksen tuotannosta. Ne kestävyyden mekanismit, jotka on voitu havaita rautapohjaisen metalliteollisuuden toiminnasta, voivat tulevaisuudessa myös päteä tyystin muiden materiaalien tuotantoon. Mikään ei takaa, että aiemmin havaitut kestävyyttä tuottaneet mekanismit riittävät rautapohjaisen metalliteollisuuden jatkumiseen, mikäli keksitään esimerkiksi vahvempia, edullisempia ja helpommin kierrätettäviä hiilikuituja. Tällöin rautapohjaisen teollisuuden jatkuvuuteen sitoutuminen vaikuttaa epätodennäköiseltä.

Edellä kuvattu esimerkki kuvaa hyvin tutkittavan asian karkaamisen logiikkaa. Se osoittaa, että terästeollisuuden jatkuminen voi vaikuttaa uhatulta juuri niistä syistä, jotka ovat tehneet siitä tähän asti kestävän. Onko juuri terästeollisuutta näin ollen lainkaan mielekästä kutsua kestäväksi? Tutkija voi tietysti laajentaa "vakioitua" asiaa ja tarkastella pelkän teräksen sijaan kaikkien rautapohjaisten metallien tuotannon kestävyyttä. Mutta tähän voidaan päätyä vasta (mahdollisesti mielivaltaisesti) jo valitun tapauksen tutkimisen jälkeen - ilman terästeollisuuden tarkastelua kestävyyden mekanismeja ei olisi koskaan löydetty. Myös rautapohjaisen metalliteollisuuden tarkastelu vaikuttaa jokseenkin mielivaltaiselta, jos kestävyyden mekanismit alkavat päteä kokonaan muunlaisten materiaalien tuotantoon. Rajaus on kuitenkin tehtävä. Tutkimuksessa on käytännön syistä mahdotonta alkaa tarkastella kaikkien mahdollisten materiaalien kaikenlaisen tuotannon kestävyyttä.

Toinen, edelliseen kiinteästi liittyvä haaste on, että tutkittavan asian ympäristön jatkuvuus on ainakin jossain määrin oletettava, jotta tutkittavan 
asian identiteetin jatkuminen olisi mahdollista. Mikään ei kuitenkaan takaa, että kestävyyden tuottavat tekijät pätisivät enää tähän identiteettiin tulevaisuudessa. Aiemmin asialle $\mathrm{z}$ kestävyyttä tuottaneista mekanismeista $\mathrm{n}$ ei voida päätellä, pätevätkö mekanismit juuri tähän asiaan enää tulevaisuudessa. Samansuuntainen huomio voidaan tehdä kestävyyttä tuottavaan mekanismiin $M$ sitoutumisesta: mikään ei takaa, että sitoutumista tuottaneet tekijät saavat ihmiset sitoutumaan juuri niihin mekanismeihin, joissa ne ovat aiemmin esiintyneet. Ihmisen luomat järjestelmät voidaan periaatteessa koska tahansa päättää purkaa ja kaikki sosiaaliset järjestelmät myös vaativat aktiivista ylläpitoa, jotta ne ylipäätään jatkuisivat.

Esimerkiksi ekologisesti ja liiketoiminnallisesti kestäväksi tehdyn osakeyhtiömuotoisen yrityksen toiminnan pohdinnassa ei välttämättä tulla huomioineeksi, että yhteiskunnassa halutaan (syystä tai toisesta) siirtyä muunlaisiin organisaatioihin kuin kapitalistisiin yrityksiin perustuvaan talousjärjestelmään. Vaikka yksittäisen liikeyrityksen toiminta olisi kuinka kestävää liiketoiminnan kontekstissa, voi itse liiketoiminnan konteksti tulla tiensä päähän. On mahdotonta ennakoida, pätevätkö tähän yritykseen tässä tilanteessa enää samat liiketalouden "rautaiset lait", joiden puitteissa se on aiemmin ollut kestävä.

Kolmas haaste on se, että kestävyyden "etukäteisessä” arvioinnissa itse kestävyyttä tuottavat emergentit ominaisuudet ja niihin sitoutuminen karkaavat aina tutkijan ulottumattomiin. Haaste näkyy kestävyyden sekä positiivisessa (so. asia x on kestävä) että negatiivisessa (so. asia x ei ole kestävä) arviossa. Mikäli kestävyys määritellään positiivisesti, on tarkasteltavan toiminnan identiteetti otettava annettuna, jolloin törmäämme osittain jo edellä kuvattuun ensimmäiseen ongelmaan. Arvioinnin kohteena ei kuitenkaan ole edes itse kestäväksi määritelty asia, vaan ainoastaan sen interaktio ympäristönsä kanssa. Jotta asian suhteita ympäristössään voisi mallintaa, on arvion perustana oltava jonkinlainen suljettu järjestelmä, jotta olosuhteiden muutosta voisi hahmottaa. Toisin sanoen arvioinnissa joudutaan tarkastelemaan "fiksatun" identiteetin kehitystä yhtä lailla "fiksatun" järjestelmän "fiksattujen" kehityskulkujen piirissä. Tämä ei tietenkään tarkoita, että tutkittavan asian identiteetti pysyisi täysin samana. Jokaisen asian identiteetti muuttuu muiden muuttujien mukana myös suljetun järjestelmän piirissä (esim. kun orja lähtee, myös herra menettää asemansa; kun mehiläiset muuttavat, kukatkaan eivät enää pölyty). Jonkinlaisia 
ennakoitavissa olevia lineaarisia kehityskulkuja on kuitenkin määriteltävä, jotta arviointi olisi mahdollista. Toisin sanoen tällä määritelmällä ei koskaan päästä käsiksi sellaisiin yllättäviin tilanteisiin ja katkoksiin, joissa resilienssiin sitoutuminen punnitaan.

Negatiivinen määritelmä on luonteeltaan aivan yhtä epävarma, mutta eri syystä. Sen avulla voidaan nostaa esiin, valikoida ja rajata joitain järjestelmän sisäisiä dynamiikkoja ja olosuhteita, ilmaista joitain raja-arvoja näiden suhteen sekä tulkita asiaa kestämättömäksi erilaisten tulevaisuuden skenaarioiden kautta. Näiden skenaarioiden ei tarvitse olla yhtä lailla lineaarisia, eikä kehityskulkujen tarvitse rajoittua järjestelmän sisäiseen logiikkaan. Negatiivisella määritelmällä ei kuitenkaan koskaan päästä käsiksi ydinkysymykseen eli siihen, mikä tarkalleen ottaen on kestävää. Toisin sanoen tällä määritelmällä ei koskaan päästä käsiksi siihen, millainen kestävän asian identiteetti olisi ja minkä suhteen resilienssiin muuttuvissa olosuhteissa sitoudutaan.

Kestävyys on edellä sanotun perusteella vaativa tutkimuskohde, oli kyse lähes minkä tahansa asian kestävyydestä. Kestävyyden todentaminen ja tutkiminen empiirisesti on väistämättä taaksepäin katsovaa eli jälkikäteistä, mutta tutkittavan asian identiteetin, validiteetin ja relevanssin suhteen epävarmaa. Mikäli taas kestävyyttä halutaan tarkastella jokin asian ominaisuutena tässä ja nyt, on kyse väistämättä arviosta, joka on luonteeltaan aksiomaattinen. Arvioon sisältyy samanlaiset tutkittavan asian identiteetin epävarmuuden haasteet. Kestävyyden tutkimuksessa on väistämättä myös oletettava jonkinlainen suljettu järjestelmä ja tarkasteltava sen sisäistä toimintalogiikkaa. Kestävyyden tutkimus on siis aina jonkun järjestelmän olemassaolon ehtojen tutkimusta: "kestävä" määräytyy aina ympäröivän järjestelmän kautta. Jotta kestävyydestä olisi mielekästä puhua, on tähän järjestelmään myös sitouduttava, eli muutoksiin on reagoitava hallitusti sen puitteissa.

\section{Hallintajärjestelmät ja järjestelmien ulkopuoli}

Olemme edellä esittäneet, että kestävyyden tutkimus vaatii sekä jonkinlaisen hallintajärjestelmän määrittelemistä että oletuksen siihen sitoutumisesta. Hallintajärjestelmällä viittaamme järjestelmään, jonka puitteissa 
voidaan määritellä tutkittavan asian identiteetti ja sen suhteet ympäristöönsä sekä arvioida järjestelmän potentiaalisia kehityskulkuja. Sitoutumisella taas viittaamme siihen, että järjestelmässä on myös sitouduttu tuottamaan tutkittavan asian jatkuvuutta olosuhteiden muuttuessa. Jälkimmäisen piirteen johdosta kestävyys sisältää aina väistämättä itse järjestelmän jatkuvuutta tuottavien piirteiden aktiivisen suojelun. Kestävyyden arviot voidaan tässä mielessä määritellä aina myös arvioiksi oletetun järjestelmän uusintamiseen sitoutumisesta.

Jokaisella järjestelmällä on tietyt uusintamisehtonsa: ekologisilla järjestelmillä luonnon kiertokulkuun ja eläviin järjestelmiin liittyvät, inhimillisillä järjestelmillä instituutioiden olemassaolon ehtoihin liittyvät (legitimiteetti, diffuusio, aktiivinen ylläpito jne.). Esimerkiksi marxilaisessa tutkimuksessa yhteiskunnan uusintamisen tapaa pidetään kokonaisia yhteiskuntamuotoja erottelevana piirteenä. Kestävyyden tutkimuksessa taas kyse vaikuttaisi olevan siitä, miten sitoutumista spesifisti määritellyn järjestelmän uusintamiseen pidetään yllä. Tällainen sitoutuminen on luonteeltaan tyypillisesti niin institutionaalista, moraalista kuin juridistakin. Yksinkertaisimmillaan uusintaminen voi tarkoittaa vaikkapa sitä, että maanviljelysjärjestelmässä siemenvilja laitetaan sivuun odottamaan seuraavaa vuotta. Tällöin sitoutuminen uusintamiseen tarkoittaa institutionaalis-normatiivista koodistoa, joka varmistaa siemenviljan säästämisen.

Uusintamiseen sitoutumisen vaatimuksen johdosta on kiinnostavaa kysyä, voidaanko kestävyyttä yleisesti arvioida millään tavalla. Jos kestävyyden oletetaan merkitsevän sitoutumista jonkin järjestelmän uusintamisen ehtoihin, se voi saada merkityksensä vain suhteessa tähän järjestelmään. Näin voi kysyä, onko kestävyyden käsitteellä ylipäätään merkitystä irrallaan sen hallintajärjestelmän logiikasta, johon kestävyyden analyysi on upotettu. Mikäli ei, johtopäätös on, että abstrakti kestävyys ei tarkoita mitään. Työhypoteesina oletamme, että tämä pitää paikkaansa. Kyse ei ole itsessään merkittävästä ongelmasta kestävyyden tutkimuksen kannalta. Se vain pakottaa tuomaan tarkasti esiin, millaisen hallintajärjestelmän puitteissa kestävyys hahmotetaan, sekä pohtimaan, millainen hallintajärjestelmä on mielekästä olettaa kestäväksi.

Kun hallintajärjestelmiä tutkitaan kestävyyden näkökulmasta, on ensinnäkin tärkeää erottaa toisistaan systeemiset ja satunnaiset piirteet. Kestävyyden uhat ovat hyvin erilaisia, mikäli niiden esiintyminen on ennakoitavissa ja 
torjuminen on rakennettu osaksi järjestelmän toimintalogiikkaa, kuin että uhat esiintyisivät satunnaisesti ja niihin oletettaisiin reagoitavan mielivaltaisesti. Erilaisten tekijöiden ottaminen mukaan hallintajärjestelmän määritelmään sisältää kuitenkin lehmänkaupan. Mitä laajemmin hallintajärjestelmä hahmotetaan eli mitä enemmän siihen sisällytetään erilaisia järjestelmällisiä tekijöitä, sitä enemmän erilaisten asioiden keskinäisiä vaikutuksia ja hallintakeinoja voidaan arvioida ja sitä validimpaa kestävyyden arviointi on. Toisaalta järjestelmän käsityksen laajentuessa se alkaa sisältää aina enemmän myös satunnaisia ja heikommin hallittavia piirteitä ja muistuttaa siten järjestyksen sijaan kaaosta. Sen kehityksestä ja hallinnasta on tämän vuoksi aina vaikeampaa esittää luotettavia arvioita. Samaa voidaan sanoa arvioiden mielekkyydestä. Esimerkiksi yrityksen liiketaloudellisen kestävyyden arviointi voi olla jossain määrin mielekästä ekstrapoloimalla odotettavissa olevien menojen ja tulojen suhdetta hamaan tulevaisuuteen, kun taas maailmansotien tai meteorien ennakointi ei vaikuta sen arvioinnin kannalta mielekkäältä.

Toinen tärkeä määrittelykysymys on järjestelmän sisäisten ja ulkoisten piirteiden välinen rajanveto. Rajanveto määrittelee suoraan, millaiset tekijät hyväksytään osaksi uusinnettavaa hallintajärjestelmää ja mitkä jätetään sen ulkopuolelle olosuhteiksi, joihin hallintajärjestelmän kautta on vain reagoitava. Tähän liittyen on erotettava myös ulkoinen shokki ja anomalia. Ulkoinen shokki on nimensä mukaisesti jotain, mikä uhkaa järjestelmää täysin sen omasta toimintalogiikasta riippumatta. Kaikki järjestelmät kohtaavat aina ulkoisia shokkeja ja täydellinen varautuminen niihin on mahdotonta. On oma kysymyksensä, miten kestävän järjestelmän kriteerit määritellään tästä näkökulmasta. Useita järjestelmiä luultavasti pidetään kestävinä, vaikka aina on periaatteessa mahdollista, että jokin ulkoinen shokki lopettaa niiden jatkuvuuden. On esimerkiksi aina mahdollista, että meteori tuhoaa pienimuotoisen luomu-kiertoviljelyjärjestelmän. Samalla tavalla kokonaisista talousjärjestelmistä on kysyttävä, minkälaiset tapahtumat ovat tarpeeksi poikkeuksellisia, että niiden mahdollisuudesta huolimatta järjestelmää voidaan pitää kestävänä.

Anomalia viittaa järjestelmän oman logiikan tuottamaan yllättävään ja poikkeavaan tapaukseen. Anomalioiden huomioiminen on tärkeää, koska ne voivat tuottaa katkoksia uusintamiseen. Asioiden kestämisen tarkastelun näkökulmasta on toki tarpeetonta vetää tällaisia rajoja - jos asia on 
kestämätön, se on kestämätön riippumatta siitä, loppuuko sen jatkuvuus ulkoisen vai järjestelmän sisäisen toimintalogiikan tai ennakoidun vai ennakoimattoman tapahtuman seurauksena. Kestävyyden arvioinnin ja kestämistä tuottavien mekanismien tunnistamisen näkökulmasta se on kuitenkin välttämätöntä. Järjestelmä voi nimittäin olla anomalioiden johdosta rakenteellisesti itsetuhoinen. Pelkkä sitoutuminen järjestelmän uusintamiseen ei siis automaattisesti riitä takaamaan sen jatkuvuutta. Esimerkiksi kapitalismia on epäilty rakenteellisesti itsetuhoiseksi niin kauan kun sitä on ollut, joko luokkaristiriitojen rakenteellisen kärjistymisen (Marx) tai kasvuun perustuvan talouden ekologisen tuhoisuuden takia (degrowth).

Rakenteellisesti itsetuhoinen järjestelmä tuhoaa itsensä nimenomaan uusintamisensa kautta: järjestelmän puitteissa voidaan olla sitoutuneita järjestelmän uusintamiseen, mutta kykenemättömiä huomaamaan, että uusintamisehtojen alla olevat järjestelyt tuottavat peruuttamattomia ristiriitoja. On siis tehtävä erottelu hallintajärjestelmän ja sen rakenteen välillä. Rakenteen voi katsoa olevan ontologisesti yksilöoliot ylittävä taso, joka ei palaudu yksilöiden intentioihin. Jo klassisessa sosiologiassa on analysoitu tähän tapaan esimerkiksi rituaaleja: ihmiset mieltävät toimintansa uskonnollisten käsitteiden kautta, kun rakenteen näkökulmasta he osallistuvat tiedostamattaan sosiaalisen koheesion ylläpitämiseen (Durkheim 1980). Hallintajärjestelmä on taas jonkinlaisen kollektiivisen tiedostetun intention ilmaisu. Ontologisesti "rakenteellinen" on näin ollen hallintajärjestelmän "takana" oleva sosiaalinen taso, joka syntyy yksilöiden toiminnasta ilman intentiota.

\section{Yhteiskuntatieteet ja poliittinen kestävyys}

Lopuksi pohdimme kestävyyden käsitteen mielekkyyttä yhteiskuntatieteissä. Yhteiskuntatieteisiin liittyy kaksi kestävyyden tutkimuksen kannalta keskeistä piirrettä. Ensinnäkin yhteiskuntatieteellinen tutkimus joutuu aina tavalla tai toisella ottamaan teoriaperustassaan kantaa niin ilmiöiden jatkuvuuden, muutoksien kuin katkoksienkin luonteeseen ja syihin (esim. March 1996, Parsons ja Shils 1951 [2001], Streeck ja Thelen 2005). Toiseksi yhteiskuntatieteiden tutkimuskohde ei koskaan ole riippumaton itse tutkimuksesta kiitos yhteiskuntatieteiden performatiivisuuden (esim. Law ja 
Urry 2004). Kuten esimerkiksi Amartya Sen (2004) on todennut, yhteiskuntatieteellinen tutkimus tapahtuu aina jostain yhteiskunnassa jo olevasta pisteestä käsin, minkä vuoksi tutkimuksessa ei voida välttää normatiivisia ja poliittisia sitoumuksia.

Edellä esitetyn tieteenfilosofisen pohdinnan myötä kestävyyden käsite näyttäisi olevan yhteiskuntatieteellisesti samanaikaisesti sekä metodologisesti hampaaton että normatiivisesti aggressiivinen. Kestävyyden arvioimisen merkittävin ongelma on järjestelmään sitoutumisen potentiaalisesti epävakaa luonne. On nimittäin aina mahdollista, että hallintajärjestelmään yksinkertaisesti päätetään olla sitoutumatta. Mitään yhteiskunnallista järjestelmää ei siis ole mielekästä olettaa poliittisesti kestäväksi. Mitä enemmän hallintajärjestelmä sisältää anomalioita ja mitä epävakaampi se rakenteellisesti on, sitä todennäköisempää "poliittinen kestämättömyys" on. Kestävyyden käsite vaikenee kuitenkin juuri silloin, kun kysytään kestävyyteen liittyviä ydinkysymyksiä: mikä saa asiat päättymään. Jatkuvuutta uhkaavia tekijöitä on väistämättä "puskettava" tarkastelukohteen ulkopuolelle, koska kaikkea ei voida sisällyttää hallintajärjestelmään. Samalla joudutaan olettamaan väistämättä yksinkertaistettu ja rajallinen hallintajärjestelmä, jonka käyttöön ja uusintamiseen on tarkoitus sitoutua. Kestävyyden "etukäteinen” arviointi yhteiskuntatieteellisesti mielekkäällä tavalla edellyttäisikin jatkuvuuksien ja katkoksien logiikoiden arviointia sekä tutkittavan asian että kestävyyden arvioinnin perustana olevan hallintajärjestelmän osalta.

Yhteiskuntatieteiden kannalta merkittävin kysymys näyttäisi sanotun perusteella olevan hallintajärjestelmän logiikan määrittely sekä sen sisä- ja ulkopuolen välinen rajanveto. Yhteiskuntatieteellisessä kontekstissa tämä seikka tekee kestävyyden käsitteestä väistämättä poliittisen. Kuten edellä todettiin, rajanveto järjestelmän sisä- ja ulkopuolen välillä on väistämättä jokseenkin mielivaltainen jo metodologisten lehmänkauppojen takia. Voidaankin sanoa, että nämä valinnat ovat luonteeltaan normatiivisia. Yhteiskuntatieteiden ja laajemmin ihmistieteiden kontekstissa normatiivisten rajanvetojen tekemiseen sisältyy eräitä lisähaasteita.

Yhteiskuntatieteellisessä tutkimuksessa ei ensinnäkään ole helppoa määritellä järjestelmien luontevaa sisä- ja ulkopuolen rajaa. Timothy Morton (2007) on käsitellyt teemaa ekologisen tutkimuksen yhteydessä. Hän esittää, ettei edes ekologisia järjestelmiä voida hahmottaa tutkimuksessa ilman ihmislajin oman aseman määrittelemistä näissä järjestelmissä. 
Koska ihmiset voivat määritellä oman asemansa ekologisten järjestelmien parissa jokseenkin vapaasti (esim. esittää lajin jatkuminen ensisijaiseksi muihin nähden, preferoida joitain ravinnonlähteitä toisten sijaan), johtavat erilaiset määritelmät myös varsin erilaisten hallintajärjestelmien olettamiseen. Mitä enemmän järjestelmä sisältää sosiaalisia piirteitä, sitä vahvempia tähän liittyvät normatiiviset lataukset ovat.

Toiseksi voi olla liian helppoa ja houkuttelevaa selittää järjestelmän sisäiset romahdukset ulkoisina shokkeina. Esimerkiksi viimeaikaiset finanssikriisit vaikuttavat syntyneen lähinnä finanssitalouden omasta toimintalogiikasta. Kuitenkin niitä on pyritty selittämään erilaisista järjestelmälle ulkoisista tekijöistä, esimerkiksi psykologisesta tekijöistä ("hysteria") (de Goede 2005) tai pelkästä epätodennäköisyydestä ("musta joutsen") (Taleb 2007) johtuviksi. On aina avoin ja osittain myös empiirinen kysymys, milloin relevantti selitys tällaiselle katkokselle perustuu järjestelmän sisäisiin tekijöihin ja milloin järjestelmälle ulkoisiin tekijöihin viittaamiseen. Ulkopuolisen vaikutuksen selittäminen on kuitenkin aina houkuttelevaa, koska sitä ei tarvitse teoretisoida. Jos ulkoisia tekijöitä aletaan analysoida, tulee niistä aina sisäisiä tekijöitä (Morton 2007). Tutkimuksen tieteelliset koulukunnat ja niiden normatiiviset sitoumukset voivat suosia säännönmukaisesti ulkoisia selityksiä, jos oma tutkimus perustuu esimerkiksi vakaan tai toivottavana pidettävän järjestelmän olettamiseen.

\section{Lopuksi: mitä kestävyydestä jää jäljelle?}

Olemme edellä käsitelleet kestävyyden käsitteen luonnetta ja käyttökelpoisuutta tieteellisessä tutkimuksessa. Käsittelyn pohjalta voidaan todeta, että kestävyyden tutkiminen ja arvioiminen on hyvin vaativaa. Teoreettisena käsitteenä kestävyys muistuttaa resilienssiä, mutta sisältää myös sitoutumisen resilienssiin jonkinlaisen ennalta määritellyn hallintajärjestelmän puitteissa. Yleisimmin kestävyyden käsite ilmenee kestävyyden arvioinnin muodossa. Tässä mielessä kestävyys on väistämättä jonkin järjestelmän mukaista kestävyyttä. Asioiden kestävyyden arviointi on aina riippuvaista siitä hallintajärjestelmästä, jonka puitteissa asian identiteetti ja odotettavissa olevat kehityskulut määritetään. Kestävyyden arviointi sisältää väistämättä oletuksen tähän hallintajärjestelmään ja sen uusintamiseen sitoutumisesta. 
Olemme edellä argumentoineet, että oletetun hallintajärjestelmän logiikan ja rakenteen sekä erityisesti sen sisä- ja ulkopuolen rajanvetojen avaaminen on tärkeää kestävyyden tutkimuksen mielekkyyden kannalta. Kestävyyden arviointi varsinkin rakenteeltaan itsetuhoisten hallintajärjestelmien kautta vaikuttaa hyvin ongelmalliselta.

Olemme tuoneet esiin myös kestävyyden arviointiin liittyviä ongelmia erityisesti yhteiskuntatieteissä. Kestävyyden käsite ei itsessään erottele riittävästi katkoksien eli asioiden kestämättömyyden syitä ollakseen yhteiskuntatieteellisesti mielekäs. Sen avulla on myös vaikeaa analysoida hallintajärjestelmän itsensä mahdollisesti sisältämiä ristiriitoja. Toisaalta sen käsitys hallintajärjestelmästä sisältää helposti hyvin yksinkertaistetun käsityksen yhteiskunnasta. Sen on myös oletettava hallintajärjestelmän aktiivinen uusintaminen, vaikka yhteiskunnalliset instituutiot voidaan periaatteessa aina päättää järjestää toisin. Tässä mielessä kestävyyden tutkimus on yhteiskunnallisesti normatiivista ja usein myös poliittista. Kestävyyden käsitettä tulisi yhteiskuntatieteissä käyttää vain silloin, kun niin tutkittavan ilmiön, sen hallintajärjestelmän kuin siihen sitoutumisen jatkuvuus, ylläpito ja katkokset voidaan kaikki arvioida ja ennakoida yhtä luotettavasti. Tällöinkin oletuksien ja siten koko tutkimuksen normatiivinen luonne on syytä tiedostaa ja tuoda esiin. Tämä nostaa kestävyyden pohjana olevan yhteiskuntateoreettisen viitekehyksen kriittisen arvioinnin erittäin keskeiseen rooliin.

Useimmiten kestävyyden analyysit esimerkiksi tyytyvät siihen, että kestävyys määritellään useamman "pilarin" kautta: ekologinen, taloudellinen ja sosiaalinen kestävyys. Näiden väliset suhteet ja osittain jopa merkitykset jäävät kuitenkin hämäriksi, eivätkä sellaisenaan riitä sen enempää empiirisen tutkimuksen kuin normatiivisen analyysin lähtökohdiksi. Nähdäksemme tässä esitettyjen työkalujen avulla käsite voidaan "pelastaa" ymmärtämällä se eksaktimmin. Tällöin kestävyyttä tutkittaisiin normatiiviselta kannalta nimenomaan tutkimuksen implikoimien sitoumusten näkökulmasta. Empiiriseltä kannalta tutkimus edellyttäisi ennen kaikkea erottelua järjestelmän sisä- ja ulkopuolen, anomalioiden ja ulkoisten shokkien sekä systeemisten (rakenteellisten) ja satunnaisten piirteiden välillä. Kestämättömyyden analyysissa on taas aina erotettava hallintajärjestelmän epäonnistumisista ja järjestelmän rakenteellisesta itsetuhoisuudesta johtuvat kestävyyden katkokset. Näiden lisäksi kenties olennaisin metodologinen 
haaste järjestelmän kestävyyden tutkijalle on määrittää suhteensa historiaan ja tulevaisuuteen: järjestelmän kestävyyden arviointi on validia vain "jälkikäteen" ja yleensä kiinnostavaa vain "etukäteen".

\section{Lähteet}

Adger, W. Neil. 2000. Social and ecological resilience: are they related? Progress in Human Geography, 24:3, 347-364.

Cox, Robert H. ja Béland, Daniel. 2013. Valence, Policy Ideas, and the Rise of Sustainability. Governance, 26:2, 307-328.

Durkheim, Emile. 1980. Uskontoelämän alkeismuodot. Australialainen toteemijärjestelmä. [Ranskankielinen alkuteos 1912.] Helsinki: Tammi.

Ehrgott, Matthias, Reimann, Felix, Kaufmann, Lutz ja Carter, Craig. R. 2010. Social Sustainability in Selecting Emerging Economy Suppliers. Journal of Business Ethics, 98:1, 99-119.

Ekins, Paul. 1999. Economic growth and environmental sustainability: The prospects for green growth. Lontoo: Routledge.

Eskelinen, Teppo. 2006. Kestävän kehityksen paradoksit. Niin ja Näin, 13:3, 73-81

Eskelinen, Teppo ja Sorsa, Ville-Pekka. 2011. Hyvä talous. Helsinki: Like.

Folke, Carl. 2006. Resilience: The emergence of a perspective for socialecological systems analyses. Global Environmental Change, 16:3, 253-267.

de Goede, Marieke. 2005. Virtue, fortune and faith: a genealogy of finance. Minneapolis, MN: University of Minnesota Press.

Hoffren, Jukka. 2006. Suomella on raskas ekologinen jalanjälki. Tiedo ja Trendit verkkoartikkeli. http://tilastokeskus.fi/tup/tietotrendit/tt_10_06_ekologinen_ jalanjalki.html [Luettu 22.11.2015]

Hussen, Ahmed. 2012. Principles of environmental economics and sustainability. An integrated economic and ecological approach. Lontoo: Routledge. 
Hutchins, Margot ja Sutherland, John W. 2008. An exploration of measures of social sustainability and their application to supply chain decisions. Journal of Cleaner Production, 16:15, 1688-1698.

Law, John ja Urry, John. 2004. Enacting the social. Economy and Society, 33:3, 390-410.

March, James. 1996. Continuity and Change in Theories of Organizational Action. Administrative Science Quarterly, 41:2, 278-287.

Merriam-Webster (2015) Merriam-Webster online dictionary. http://www. merriam-webster.com/. [Luettu 22.11.2015]

Morton, Timothy. 2007. Ecology Without Nature: Rethinking Environmental Aesthetics. Cambridge, MA: Harvard University Press.

Oxford [Oxford English Dictionary]. 2015. Oxford online dictonary. http:// www.oxforddictionaries.com/. [Luettu 22.11.2015]

Parsons, Talcott ja Shils, Edward. 1951 [2001]. Toward a General Theory of Action: Theoretical Foundations for the Social Sciences. Uusintapainos Neil Smelserin johdannolla. New Brunswick, NJ: Transaction Publishers.

Sen, Amartya. 2004. Rationality and freedom. Cambridge, MA: Harvard University Press.

Sorsa, Ville-Pekka. 2014. Kestävyysvajeen politiikkaidean kritiikki. Politiikka, $56: 2,132-142$.

Streeck, Wolfgang ja Thelen, Kathleen. 2005. Beyond Continuity: Institutional Change in Advanced Political Economies. Oxford: Oxford University Press.

Taleb, Nassim Nicholas. 2007. The black swan: the impact of the highly improbable. Lontoo: Allen Lane.

WCED [World Commission of Environment and Development]. 1987. Our common future. Oxford: Oxford University Press. 